\title{
Peranan Kompetensi Dalam Meningkatkan Kinerja Karyawan PT. Summit Oto Finance
}

\author{
Shandra Bahasoan \\ STIE NOBEL \\ Email: sanradewi204@gmail.com
}

\begin{abstract}
The study was conducted aimed at knowing the role of competencies, namely knowledge, skills and self-concept in improving the performance of employees of PT. Summit Oto Finance, with a sample of 54 people. The method used in this study using questionnaires, interviews and documentation. Research approach by using quantitative descriptive method by analyzing Multiple Linear Regression to measure the performance of employees of PT. Summit Oto Finance. The results of this study simultaneously independent competency variables consisting of knowledge, skills and self-concept have a positive and significant influence on the dependent variable, namely employee performance. From the test results the correlation of the influence of competencies on employee performance is 94.1 percent while 5.9 percent is influenced by other factors. Dominant competencies affect the performance of employees of PT. Summit Oto Finance is a skill.
\end{abstract}

Keywords: Competence, Employee Performance

\section{Abstrak}

Penelitian dilakukan bertujuan untuk mengetahui peran dari kompetensi yaitu pengetahuan, keterampilan dan konsep diri pada peningkatan kinerja karyawan PT. Summit Oto Finance, dengan jumlah sampel 54 orang. Metode yang digunakan dalam penelitian ini dengan menggunakan kuesioner, wawancara dan dokumentasi. Pedekatan penelitian dengan menggunakan metode diskriptid kuantitatif dengan cara menganalisis Regresi Linier Berganda untuk mengukur kinerja karyawan PT. Summit Oto Finance. Hasil penelitian ini secara serempak variabel bebas kompetensi yang terdiri dari pengetahuan, keterampilan dan konsep diri memiliki pengaruh positif dan signifikan terhadap variabel terikat yaitu kinerja karyawan. Dari hasil pengujian korelasi pengaruh kompetensi terhadap kinerja karyawan sebesar 94,1 persen sedangkan 5,9 persen dipengaruhi oleh faktor lain. Kompetensi yang dominan mempengaruhi kinerja karyawan PT. Summit Oto Finance adalah keterampilan.

Kata kunci: Kompetensi, Kinerja Pegawai

\section{Pendahuluan}

Pembiayaan di Indonesia memasuki masa persaingan yang sangat kompetitif. Banyaknya pembiayaan yang beroperasi di Indonesia baik yang beroperasi secara lokal maupun yang beroperasi berskala internasional. Pembiayaan mampu bertahan melewati masa krisis moneter untuk memberikan layanan terbaiknya kepada kreditur melalui berbagai macam produk kredit seperti produk dana, produk pinjaman atau produk jasa lainnya. Pasar kredit, pembiayaan memiliki beberapa jenis kredit yang umum ditawarkan kepada nasabah antara lain kredit: korporasi, kredit modal kerja, investasi, kredit konsumtif, dan kredit mikro. Pada era perdagangan bebas saat ini, perusahaan dituntut untuk membangun sebuah sistem manajemen secara professional. Pertimbangan utama perusahaan untuk melakukan retensi kepada pelanggan yang pertama karena semakin mahal biaya perolehan pelanggan baru dalam iklim kompetisi yang ketat, selain itu tingkat kemampuan laba perusahaan berbanding lurus dengan pertumbuhan hubungan antar pelanggan secara permanen.

PT. Summit Oto Finance merupakan perusahaan yang bergerak pada bidang pembiayaan dengan segala merek kendaraan bermotor dan saat ini bukan barang mewah lagi tetapi menjadi suatu kebutuhan masyarakat. Hal ini telah terbukti dengan banyaknya pengguna kendaraan bermotor baik di daerah perkotaan atau pedesaan. Salah satu contohnya adalah pembelian kendaraan bermotor dengan sistem kredit dan dengan relative ringan dengan uang 
muka yang bisa disesuaikan. Persaingan yang ada di antara perusahaan pembiayaan otomotif di Makassar semakin ketat, hal ini dikarenakan adanya persaingan antar pembiayaan di Kota Makassar. Perusahaan dituntut untuk memupuk keunggulan yang kompetitif masing-masing melalui upaya-upaya yang kreatif, inovatif serta efisien sehingga menjadi pilihan dari banyak pelanggan yang diharapkan untuk tetap setia.

Kinerja adalah hasil tingkatan keberhasilan kerja dari seseorang secara keseluruhan selama dalam periode tertentu untuk melaksanakan tugasnya, seperti standar hasil kerja, target ataupun sasaran maupun kriteria yang telah ditentukan terlebih dahulu dan telah disepakati bersama. Menurut Rivai dan Basri (2005). Selanjutnya menurut Mangkunegara (2005) kinerja merupakan hubungan antara kemampuan dan motivasi kerja yang dijalankan berdasarkan fungsinya. Oleh sebab itu dalam peningkatan kinerja individu harus dilakukan pembinaan kemampuan serta motivasi kerja pegawai.

Dari hasil pengamatan PT. Summit Oto Finance menjadi barometer dalam pencapaian kinerja tetapi kenyataannya kinerja karyawannya tidak maksimal. Nampak aktivitas yang dilakukan oleh sebagian karyawan tidak produktif, terdapat 33 persen karyawan yang terlambat masuk kantor dan pulang tidak tepat waktu. Pelatihan yang dilakukan dalam 2 tahun terakhir tidak ada, dan terlihat karyawan yang tidak professional dalam memberikan pelayanan kepada masyarakat maupun kerjasama dalam lingkungan kerja dan kebiasaan untuk menunda pekerjaan serta menunggu perintah atasan saja.

\section{Literature Review}

Kepemimpinan secara harfian berasal dari kata pimpin. Kata pimpin mengandung pengertian mengarahkan, membina atau mengatur, menuntun dan juga menunjukkan ataupun mempengaruhi. Pemimpin mempunyai tanggung jawab baik secara fisik maupun spiritual terhadap keberhasilan aktivitas kerja dari yang dipimpin, sehingga menjadi pemimpin itu tidak mudah dan tidak akan setiap orang mempunyai kesamaan di dalam menjalankan kepemimpinannya. Miftah Thoha (2010) kepemimpinan adalah kegiatan untuk memengaruhi perilaku orang lain, atau seni memengaruhi perilaku manusia baik perorangan maupun kelompok. Martinis Yamin dan Maisah (2010) mandefinisikan kepemimpinan sebagai suatu group proses yang dilakukan oleh seseorang dalam mengelola dan menginspirasikan sejumlah pekerjaan untuk mencapai tujuan organisasi melalui aplikasi teknik- teknik manajemen.

Pemimpin adalah mereka yang menggunakan wewenang formal untuk mengorganisasikan, mengarahkan, mengontrol para bawahan yang bertanggung jawab, supaya semua bagian pekerjaan dikoordinasi demi mencapai tujuan perusahaan. Pemimpin pertama-tama harus seorang yang mampu menumbuhkan dan mengembangkan segala yang terbaik dalam diri para bawahannya. Secara sederhana pemimpin yang baik adalah seorang yang membantu mengembangkan orang lain, sehingga akhirnya mereka tidak lagi memerlukan pemimpinnya itu.

Menurut Oemar Hamalik dalam Martinis Yamin dan Maisah (2010) motivasi memiliki dua sifat, yakni (a) motivasi intrinsik, (b) motivasi ekstrinsik. Tentunya antara motivasi intrinsik dan motivasi ekstrinsik bermakna berbeda tetapi sangat berkaitan dalam membentuk dorongan manusia dalam melakukan sesuatu. Kebutuhan kekuasaan dapat menjadi motivasi bagi seseorang untuk bekerja dengan lebih baik untuk mencapai kekuasaan dan dihormati 
dengan cara orang yang bersangkutan bekerja dengan mengarahkan segala kemampuan yang ada pada dirinya. Kebutuhan kekuasaan akan tampak pada diri seseorang yang ingin mempunyai pengaruh terhadap orang-orang lain. Faktor pendorong penting yang menyebabkan manusia bekerja, adanya kebutuhan yang harus dipenuhi. Aktivitas kerja mengandung unsur suatu kegiatan sosial, menghasilkan sesuatu, dan pada akhirnya bertujuan untuk memenuhi kebutuhannya As'ad (2000). Motivasi yang ada di dalam dunia kerja biasanya disebut dengan motivasi kerja. Sedangkan motif adalah tenaga pendorong yang mendorong manusia untuk bertindak atau suatu tenaga di dalam diri manusia yang menyebabkan manusia bertindak.

Lingkungan kerja adalah tempat di mana pegawai melakukan aktivitas setiap harinya.Lingkungan kerja yang kondusif memberikan rasa aman dan memungkinkan pegawai untuk dapat bekerja optimal. Lingkungan kerja dapat mempengaruhi emosional pegawai. Jika pegawai menyenangi lingkungan kerja di mana dia bekerja, maka pegawai tersebut akanbetah di tempat kerjanya, melakukan aktivitasnya sehingga waktu kerja dipergunakan secara efektif. Setiap orang memerlukan 5 (lima) kebutuhan yang telah dikemukakan oleh Maslow sebagaimana diuraikan di atas sebagai sumber lingkungan kerja dalam rangka meningkatkan semangat kerjanya. Namun yang paling penting bagi seseorang adalah lingkungan kerjanya, dimulai dari dalam dirinya sendiri sesuai dengan pendapat Terry dalam Hasibuan (2001) bahwa Lingkungan kerja yang paling berhasil pengarahan diri sendiri oleh pekerja yang bersangkutan.

Kinerja adalah hasil seseorang secara keseluruhan selama periode tertentu didalam melaksanakan tugas, seperti standar hasil kerja, target atau sasaran kriteria yang telah ditentukan terlebih dahulu dan telah disepakati bersama. Veithzal (2005). Kinerja karyawan tidak hanya sekedar informasi untuk dapat dilakukannya promosi atau penetapan gaji bagi perusahaan. Akan tetapi bagaimana perusahaan dapat memotivasi karyawan dan mengembangkan satu rencana untuk memperbaiki kemerosotan kinerja dapat dihindari. Penilaian kinerja dikenal dengan istilah "performance rating" atau "performance appraisal". Menurut munandar (2008), penilaian kinerja adalah proses penilaian ciri-ciri kepribadian, perilaku kerja, dan hasil kerja seseorang tenaga kerja atau karyawan (pekerja dan manajer), yang dianggap menunjang unjuk kerjanya, yang digunakan sebagai bahan pertimbangan untuk pengambilan keputusan tentang tindakan-tindakan terhadap bidang ketenagakerjaan.

\section{Metodologi Penelitian}

Pada penelitian ini menggunakan analisis dari keadaan yang sebenarnya melihat permasalahan dan tujuan penelitian secara terperinci dan aktual. Penelitian ini menggunakan metode kuantitatif peneliti membandingkan, menghubungkan serta mengelompokkan variabel. Alasan menggunakan pendekatan kuantitaif karena untuk memecahkan persoalan yang dihadapi. Dalam penelitian ini bersifat eksplanatory dengan menjelaskan hhubungan kausalitas antara variabel independen dan variabel dependent yang terdiri dari pengetahuan, keterampilan dan konsep diri sebagai variabel independen serta variabel dependen yaitu kinerja karyawan PT. Summit Oto Finance Makassar. Lokasi penelitian dilakukan di PT. Summit Oto Finance Makassar dengan pertimbangan lokasi berdasarkan data dan informasi yang mudah dan relevan mengenai objek penelitian. 


\section{Hasil dan Pembahasan}

Karakteristik responden adalah gambaran dari keseluruhan populasi yang digunakan sebagai sampel dalam penelitian ini, data ataupun informasi yang diperoleh terkait dengan pengaruh dari pengetahuan, keterampilan dan konsep diri terhadap Kinerja Karyawan pada PT. Summit Oto Finance Makassar. Berdasarkan hasil penelitian diperoleh data responden mengenai pendidikan terakhir, umur, jenis kelamin, masa kerja dan golongan, yang dapat dijadikan masukan bagi beberapa variabel yang diteliti dalam penelitian ini. Untuk lebih jelasnya dapat disajikan uraian mengenai deskripsi karakteristik yaitu sebagai berikut :

\begin{tabular}{|c|c|c|}
\hline Tingkat Pendidikan & $\begin{array}{c}\text { Frekuensi } \\
(\mathbf{F})\end{array}$ & $\begin{array}{c}\text { Persentase } \\
(\boldsymbol{\%})\end{array}$ \\
\hline SMU & 11 & 20.4 \\
\hline D3 & 27 & 50.0 \\
\hline S1 & 16 & 29.6 \\
\hline Jumlah & $\mathbf{5 4}$ & $\mathbf{1 0 0}$ \\
\hline
\end{tabular}

Sumber : data diolah, 2019

Berdasarkan tabel tersebut diatas, dapat diketahui bahwa tingkat pendidikan S1 sebanyak 16 responden atau 29.6 persesn, pendidikan D3 sebanyak 27 responden atau 50.0 persen, pendidikan SMU sebensar 11 responden atau 20.4 responden. Kondisi ini menunjukkan unit analisis dalam penelitian ini didominasi oleh tingkat pendidikan tertinggi adalah S1 sebanyak 27 responden atau 50.0 persen. Hal ini menunjukkan tingkat pendidikan karyawan sangat diperhitungkan serta ketangkasan dalam bekerja juga diperlukan Kinerja Karyawan pada PT. Summit Oto Finance Makassar dan cukup mampu dalam menjalankan tugas-tugas yang diberikan sesuai dengan kemampuannya.

\begin{tabular}{|c|c|c|}
\hline $\begin{array}{c}\text { Umur } \\
\text { (Tahun) }\end{array}$ & $\begin{array}{c}\text { Frekuensi } \\
(\mathbf{F})\end{array}$ & $\begin{array}{c}\text { Persentase } \\
(\boldsymbol{\%})\end{array}$ \\
\hline $20-30$ & 19 & 35.3 \\
\hline $31-40$ & 31 & 57.7 \\
\hline$>40$ & 4 & 7.5 \\
\hline Jumlah & $\mathbf{5 4}$ & $\mathbf{1 0 0}$ \\
\hline
\end{tabular}

Sumber : data diolah, 2019

Kondisi ini menunjukkan unit analisis dalam penelitian ini didominasi oleh tingkat umur 31 40 tahun sebanyak 31 responden atau 57.7 persen. Tingginya persentase umur Kinerja Karyawan pada PT. Summit Oto Finance Makassar bahwa Karyawan memiliki semangat yang tinggi sehingga semua jenis pekerjaan dilaksanakan dengan cepat.

\begin{tabular}{|c|c|c|}
\hline Jenis Kelamin & $\begin{array}{c}\text { Frekuensi } \\
(\mathbf{F})\end{array}$ & $\begin{array}{c}\text { Persentase } \\
(\mathbf{\%})\end{array}$ \\
\hline Laki-Laki & 31 & 57.4 \\
\hline Perempuan & 23 & 42.6 \\
\hline Jumlah & $\mathbf{5 4}$ & $\mathbf{1 0 0}$ \\
\hline
\end{tabular}

Sumber data : data diolah, 2019

Berdasarkan tabel tersebut diatas, dapat diketahui bahwa jenis kelamin laki-laki sebesar 31 responden atau sebesar 57.4 persen dan perempuan 23 responden atau 42.6 persen. Hal ini 
wajar karena dalam pelaksanaan tugas dan fungsi membutuhkan Karyawan laki-laki yang lebih cepat dalam bekerja.

\begin{tabular}{|c|c|c|}
\hline $\begin{array}{c}\text { Masa Kerja } \\
\text { (Tahun) }\end{array}$ & $\begin{array}{c}\text { Frekuensi } \\
(\mathbf{F})\end{array}$ & $\begin{array}{c}\text { Persentase } \\
(\mathbf{\%})\end{array}$ \\
\hline $1-3$ & 3 & 5.6 \\
\hline $4-6$ & 31 & 57.4 \\
\hline$>7$ & 20 & 37.1 \\
\hline Jumlah & $\mathbf{5 4}$ & $\mathbf{1 0 0}$ \\
\hline
\end{tabular}

Sumber : Data diolah, 2019

Kondisi ini menunjukkan unit analisisnya didominasi oleh masa kerja 4-6 tahun sebesar 31 atau 57,4 persen. Tingginya persentase masa kerja karyawan pada Kinerja karyawan PT Summit Oto Finance Makassar mengisyaratkan bahwa karyawan relative bekerja lama memiliki pengalaman dalam bekerja dengan baik.

\section{Pengujian Hipotesis Secara Serempak}

Pengujian ini bertujuan untuk melihat pengaruh kepemimpinan, motivasi dan lingkungan kerja terhadap kinerja Karyawan pada PT. Summit Oto Finance Makassar. dengan melihat nilai F-hitungnya. Adapun hasil pengujian secara serempak, dapat dilihat pada tabel berikut ini.

Pengujian Secara Serempak (Uji-F)

ANOVA $^{\mathrm{a}}$

\begin{tabular}{|ll|r|r|r|r|r|}
\hline \multicolumn{1}{|l|}{ Model } & \multicolumn{1}{|c|}{$\begin{array}{c}\text { Sum of } \\
\text { Squares }\end{array}$} & Df & Mean Square & F & Sig. \\
\hline \multirow{3}{*}{1} & Regression & 13.588 & 3 & 4.529 & 263.614 & $.000^{\mathrm{b}}$ \\
& Residual & .859 & 50 & .017 & & \\
& Total & 14.448 & 53 & & & \\
\hline
\end{tabular}

a. Dependent Variable: Y

b. Predictors: (Constant), X3, X2, X1

Data pada tabel di atas menunjukkan bahwa nilai F-hitung yang diperoleh yaitu 263.614, sedangkan F-tabel pada selang kepercayaan 95\% atau tingkat kesalahan $(\alpha=0,05)$ akan diperoleh angka 4.529. Dengan demikian, nilai F-hitung > F-tabel atau $263.614>4.529$ yang berati, variabel bebas akan berpengaruh serempak dengan variabel dependent. Signifikansi tinggi karena 0,000 lebih kecil dari tingkat alpha sebesar 0,05. Hal ini dapat ditarik kesimpulan bahwa secara serempak variabel pengetahuan, keterampilan dan konsep diri berpengaruh positif dan signifikan terhadap kinerja Karyawan pada PT. Summit Oto Finance Makassar.

\section{Pengujian Hipotesis Secara Parsial}

Pengujian Hipotesis secara parsial ini digunakan untuk melihat pengaruh dari variabel pengetahuan, keterampilan dan konsep diri terhadap kinerja Karyawan pada PT. Summit Oto Finance Makassar. Hasil pengujiannya dapat dilihat dari nilai t-hitungnya. 


\begin{tabular}{|l|c|c|c|}
\hline \multicolumn{1}{|c|}{ Variabel Independent } & $\begin{array}{c}\text { Koefisien } \\
\text { Regresi (B) }\end{array}$ & t- hitung & Sig \\
\hline Pengetahuan (X1) & 0,080 & 2.106 & 0,040 \\
Keterampilan (X2) & 0,467 & 6.183 & 0,000 \\
Konsep diri (X3) & 0,422 & 5.026 & 0,000 \\
\hline \multicolumn{1}{|c|}{ Konsatanta (b b $_{0}$} & \multicolumn{3}{|l}{} \\
\hline
\end{tabular}

Sumber :Data Statistik yang diolah 2019

Berdasarkan pengujian secara parsial seperti pada tabel di atas menunjukkan bahwa variabel pengetahuan, keterampilan dan konsep diri berpengaruh positif dan signifikan terhadap kinerja Karyawan pada PT. Summit Oto Finance Makassar. Hal ini dapat diketahui dari nilai t-hitung yang diperoleh lebih besar dari t-tabel atau t-hitung lebih kecil dari t-tabel. Hasil analisis juga menunjukkan dari kedua variabel yang berpengaruh, ternyata variabel keterampilan mempunyai pengaruh dominan dalam meningkatkan kinerja Karyawan pada PT. Summit Oto Finance Makassar.

Besarnya kontribusi yang diberikan dari variabel pengetahuan, keterampilan dan konsep diri terhadap kinerja Karyawan pada PT. Summit Oto Finance Makassar dan dapat dilihat dari koefisien determinasinya. Perolehan nilai determinasi $\left(\mathrm{R}^{2}\right)$ dapat dilihat pada tabel dibawah ini:

\section{Hasil pengujian Koefisien Determinasi $\left(\mathbf{R}^{2}\right)$}

Model Summary

\begin{tabular}{|l|c|r|r|r|r|r|r|r|r|}
\hline $\begin{array}{l}\text { Mo } \\
\text { del }\end{array}$ & $\mathbf{R}$ & $\mathbf{R}$ & $\begin{array}{c}\text { Adjusted } \\
\text { Square }\end{array}$ & R Square & $\begin{array}{l}\text { Std. Error of } \\
\text { the Estimate }\end{array}$ & \multicolumn{4}{|c|}{ Change Statistics } \\
\cline { 6 - 9 } & & & & $\begin{array}{l}\text { R Square } \\
\text { Change }\end{array}$ & $\begin{array}{c}\text { F } \\
\text { Change }\end{array}$ & df1 & df2 & $\begin{array}{c}\text { Sig. F } \\
\text { Change }\end{array}$ \\
\hline 1 & $\mathbf{. 9 7 0}^{\mathbf{a}}$ & $\mathbf{. 9 4 1}$ & $\mathbf{. 9 3 7}$ & .1311 & .941 & 263.61 & 3 & 72 & .000 \\
\hline
\end{tabular}

a. Predictors: (Constant), X3, X2, X1

b. Dependent Variable: Y

Berdasarkan hasil uji determinasi tabel tersebut diatas, maka dapat dijelaskan bahwa besarnya koefisien determinasi $\left(\mathrm{R}^{2}\right)$ adalah 0,941. Angka koefisien determinasi menyatakan bahwa variabel pengetahuan, keterampilan dan konsep diri hanya dapat menjelaskan atau memberikan kontribusi atas variasi perubahan kinerja karyawan sebesar 94,1\%. Sedangkan sisanya sebesar 5,9\% dipengaruhi oleh variabel-variabel lain yang tidak dilibatkan dalam penelitian ini.

\section{Pembahasan}

Berdasarkan hasil pengujian secara statistik dapat terlihat dengan jelas bahwa secara parsial (individu) semua variabel bebas berpengaruh terhadap variabel terikat. Pengaruh yang diberikan ketiga variabel bebas tersebut bersifat positif artinya pengetahuan, keterampilan dan konsep diri terhadap kinerja Karyawan pada PT. Summit Oto Finance Makassar. Hasil tersebut sesuai dengan hipotesis yang diajukan dan hasil penelitian ini juga sesuai dengan hasil penelitian sebelumnya. Penjelasan dari masing-masing pengaruh variabel dijelaskan sebagai berikut: 


\section{Pengetahuan memiliki pengaruh terhadap Kinerja Karyawan PT.Summit Oto Finance Makassar}

Pengetahuan secara parsial memiliki pengaruh yang positif dan signifikan terhadap kinerja karyawan PT. Summit Oto Finance Makassar, berarti bahwa semakin baik pengetahuan yang dimiliki maka kinerja karyawan akan semakin baik pula. Dengan mendahulukan untuk mengikuti peraturan yang berkaitan dengan urusannya tugas dan tanggung jawab karyawan tersebut baru kemudian santai dan beristirahat setelah tugasnya selesai. Menurut Yuniarsih dan Suwatno (2008) bahwa "Pengetahuan adalah suatu informasi yang dimiliki seseorang khususnya pada bidang spesifik". Pengetahuan karyawan turut menentukan berhasil tidaknya pelaksanaan tugas yang dibebankan kepadanya, karyawan yang mempunyai pengetahuan yang cukup akan meningkatkan efisiensi perusahaan.

Fakta yang terjadi di tempat penelitian menunjukkan bahwa suatu kondisi pengetahuan yang dimiliki karyawan PT. Summit Oto Finance Makassar adalah dengan selalu mendahulukan untuk mengikuti aturan yang berlaku berkaitan dengan penyelesaian pekerjaannya, walaupun misalnya pada saat mereka bekerja terjadi kesalahan bukan menjadikan hal yang berarti karena telah mengikuti prosedur yang ditetapkan oleh perusahaan.

\section{Keterampilan memiliki pengaruh terhadap Kinerja Karyawan PT.Summit Oto Finance Makassar}

Keterampilan secara parsial berpengaruh positif dan signifikan pada peningkatan kinerja pegawai PT. Summit Oto Finance Makassar artinya bahwa adanya peningkatan variabel keterampilan maka terjadi peningkatan kinerja karyawan. Hal ini dapat dilihat dari tindakan yang dilakukan oleh karyawan untuk mendukung kelancaran dalam bekerja dengan memanfaatkan keterampilan yang dimiliki dan memberi teguran bagi pegawai yang melanggar aturan. Keterampilan menjadi dasar bagi seorang karyawan dalam menyelesaikan pekerjaanya dengan baik. Menurut Hasibuan (2000) keterampilan merupakan kemampuan seseorang dalam menyelesaikan tugas yang mencakup teknikal skill, human skill, conceptual skill dalam mencapai tujuan perusahaan.

Faktanya bahwa keterampilan pada PT. Summit Oto Finanace Makassar dipengaruhi oleh tindakan yang selalu mendukung agenda yang telah dijadwalkan guna peningkatan kinerja karyawan, dan yang melanggar aturan akan diberikan sanksi. Kompetensi yang berupa Keterampilan merupakan kemampuan yang dimiliki oleh karyawan untuk dapat mempercepat pencapaian tujuan organisasinya agar dapat berprestasi untuk meningkatkan kinerja.

\section{Konsep diri memiliki pengaruh terhadap Kinerja Karyawan PT.Summit Oto Finance Makassar}

Konsep diri secara parsial berpengaruh pada kinerja karyawan secara positif dan signifikan PT. Summit Oto Finance Makassar. Pengaruh konsep diri dapat dilihat dari adanya kerjasma dengan orang lain dalam satu tim kerja jauh lebih baik daripada bekerja sendiri. Menurut Hasibuan (2005) Prestasi Kerja atau Kinerja adalah suatu hasil kerja yang dicapai sesorang dalam melaksanakan tugas-tugas yang dibebankan kepadanya yang didasarkan atas kecakapan, pengalaman, dan kesungguhan serta waktu.

Faktanya bahwa konsep diri harus dimiliki oleh setiap karyawan untuk dapat menunjang pekerjaannya serta Konsep diri merupakan pandangan mengenai dirinya sendiri yang unik. Unik disini maksudnya adalah pandangan individu tentang dirinya sendiri, berbeda dengan 
pandangan yang dimiliki orang lain mengenai individu tersebut sehingga dapat meningkatkan kinerja karyawan pada PT. Summit Oto Finance Makassar.

\section{Simpulan}

Pengetahuan secara simultan berpengaruh positif terhadap kinerja karyawan pada PT. Summit Oto Finance Makassar Artinya bahwa semakin baik pengetahuan maka kinerja karyawan pada PT. Summit Oto Finance Makassar semakin baik pula. Maka hipotesis pertama Ha diterima Ho ditolak yang dapat disimpulkan bahwa apabila terjadi peningkatan variabel pengetahuan maka akan mempengaruhi peningkatan kinerja karyawan tersebut.

Keterampilan secara simultan berpengaruh positif terhadap kinerja karyawan pada PT. Summit Oto Finance Makassar Artinya bahwa semakin baik keterampilan maka kinerja karyawan pada PT. Summit Oto Finance Makassar maka akan semakin baik pula. Maka hipotesis kedua diterima karena nilai signifikansinya lebih kecil dari Ho yang dapat disimpulkan bahwa apabila terjadi peningkatan variabel keterampilan maka akan mempengaruhi peningkatan kinerja karyawan tersebut.

Konsep diri secara simultan berpengaruh positif dan signifikan terhadap kinerja karyawan pada PT. Summit Oto Finance Makassar Artinya bahwa semakin baik peningkatan variabel maka kinerja karyawan pada PT. Summit Oto Finance Makassar semakin baik pula. Maka hipotesis ketiga dapat diterima karena signifikansi nya kurang dari 0,05 maka Ho ditolak yang dapat disimpulkan bahwa apabila terjadi peningkatan variabel konsep diri maka akan mempengaruhi peningkatan kinerja karyawan tersebut.

Faktor yang dominan memiliki pengaruh terhadap kinerja karyawan PT. Summit Oto Finance Makassar adalah keterampilan. Dengan besar persentasenya adalah 94,1 persen. Berdasarkan simpulan diatas, maka dapat disampaikan saran yang pertama Diharapkan Kepada Kantor PT. Summit Oto Finance Makassar dapat mempertahankan antara karyawan dapat saling bekerja sama serta peran pimpinan dalam berkomuniksi dapat ditingkatkan sehingga kinerja karyawan akan terwujud sesuai keinginan bersama, kedua Diharapkan Kepada Kantor PT. Summit Oto Finance Makassar selalu memperhatikan juga mempertahankan kesejahteraan karyawannya dan peningkatan pengetahuan sesuai dengan jenis pekerjaan mereka masingmasing sehingga karyawan dapat bekerja lebih baik dan kinerja yang diinginkan dapat tercapai, ketiga Diharapkan Kepada Kantor PT. Summit Oto Finance Makassar agar menempatkan karyawannya sesuai dengan keterampilan masing-masing dan tidak berdasarkan kedekatan terhadap karyawan sehingga tidak menimbulkan kecemburuan antara karyawan pada kantor tersebut supaya dapat meningkatkan kinerjanya dan keempat Diharapkan Kepada Kantor PT. Summit Oto Finance Makassar agar menempatkan karyawannya sesuai dengan konsep diri masing-masing dan tidak berdasarkan kedekatan terhadap pimpinan sehingga tidak menimbulkan kecemburuan antara karyawan pada kantor tersebut supaya dapat meningkatkan kinerjanya.

\section{Daftar Pustaka}

As'ad. (2000). Psikologi Industri .Ed 4, Yogjakarta: Liberty

Anwar Prabu Mangkunegara. (2005). Manajemen Sumber Daya Manusia

Hasibuan, Malayu. (2001). Manajemen Sumber Daya Manusia:Pengertian Dasar, Pengertian, dan Masalah. Jakarta: PT. Toko Gunung Agung

Hasibuan, Malayu SP. (2000). Manajemen Sumber Daya Manusia, STIE YKPN, Yogyakarta. 
Hasibuan, Malayu S.P. (2006). Manajemen Sumber Daya Manusia (Edisi Revisi). Bumi Aksara. Jakarta.

Mangkunegara, A.A. Anwar Prabu. (2005). Evaluasi Kinerja SDM. Refika Aditama. Bandung.

Thoha, Miftah. (2010). Kepemimpinan Dalam Manajemen, Jakarta : Rajawali Pers.

Rivai, Veithzal. (2005). Performance Appraisal PT. Raja Grapindo Persada, Jakarta.

Rivai, Veithzal dan Basri. (2005). Performance Appraisal, Sistem Yang Tepat Untuk Menilai Kinerja Pegawai Dan Meningkatkan Daya Saing Perusahaan. Rajagrafindo Persada. Jakarta

Tjutju Yuniarsih dan Suwatno. (2008). Manajemen Sumber Daya Manusia. Bandung : Alfabeta

Yamin, Martinis dan Maisah. (2010). Standarisasi Kinerja Guru. Jakarta: Persada Press.

\section{Acknowledgement}

Penelitian ini didukung oleh kampus STIE Nobel Makassar. Kami berterima kasih kepada rekan-rekan kami seluruh karyawan pada Kantor PT. Summit Oto Finance Makassar yang memberikan wawasan dan keahlian yang sangat membantu penelitian, meskipun interpretasi yang kurang berkenan dari berbagai pihak yang ada dalam makalah ini.

\section{Copyright Disclaimer}

Copyright for this article is retained by the author(s), with first publication rights granted to the journal. 